\section{What IS to Be Done?}

Without question, there is anarchy in the realm of knowledge communication in the twenty-first century. A combination of mass production of scientific papers, most of little scholarly value, tremendous pressure on academics to publish their work regardless of ethical considerations, the communications and publishing revolution made possible by the Internet, the greed of the established multinational publishers, and the huge new coterie of fake publishers have all combined to produce confusion. The issues involved are complex-how to manage technology, accommodate the expansion of scientific production, rationalize peer review, break the monopoly of the multinationals, and, of great importance, instill a sense of ethics and realistic expectations into the academic community itself. The implications of these changes for journals published in languages other than English and in countries other than the main publishing countries are also unclear. It is likely they will be weakened by these global trends. Questions abound, answers are few.

DOI: http://dx.doi.org/Io.6oI7/ihe.20I8.92.9786

\section{Globalizing the Academic Presidency: Competing for Talented Leadership}

\section{RICHARD A. SKIN NER}

Richard A. Skinner is senior consultant, Harris Search Associates, and served as president of Royal Roads University in Canada and Clayton State University in the United States. E-mail: rick@harrisandassociates.com.

Tigher education is not immune to globalization. Rare 1 today is the research-intensive university that does not promote and support students and professors spending time abroad and, while still modest in number, foreignborn and/or -educated presidents are increasingly selected to lead universities in other countries.

\section{Two EXAm PLes}

American universities were among the first to benefit from attracting an influx of foreign-born scholars, thinkers, and researchers immigrating to the United States, beginning in the late I930s but especially during and after the Second World War. When, in I965, American immigration laws changed, there was steady growth thereafter in the numbers of students-particularly from India, South Korea, and Taiwan-seeking to attend American universities, earn advanced degrees, and remain in the United States on faculties and as department chairs, deans, provosts, and presidents.

Today, presidents of the 60 American member institutions of the Association of American Universities (AAU) - the most prestigious of all American researchintensive universities-number I2 foreign-born persons among them, with representatives from Australia, China, India, and Venezuela. To provide some perspective on that number, consider that a generation earlier, in 1992, six of the same American AAU institutions had presidents who hailed from Canada, China, Germany, Iran, Norway, and Sweden.

Among the AAU presidents are two who suggest just how internationally mobile experienced presidents are and how much they are valued at least in part, it seems, for their experience in countries other than their respective native one. Jean-Lou Chameau, a Frenchman and Stanford alumnus, resigned the presidency of Cal Tech in order to lead King Abdullah University of Science \& Technology in Saudi Arabia. And when Subra Suresh, a native of India, resigned the presidency of Carnegie Mellon University to accept appointment as president of Nanyang Technological University in Singapore, he was replaced on an interim basis by Provost Farnam Jahanian, who immigrated from Iran.

A second example of the globalization of university leadership can be observed in the Times Higher Education (THE) World University Rankings for 2017 for non-American institutions (25) among the 50 highest-ranked institutions, and noting the international education and employment paths of their respective heads:

- Australian National University: born in the United States and earned degrees from the University of Arizona and Harvard University.

- École Polytechnique de Lausanne: Master's from Stanford University and on faculties of Columbia University and the University of California (UC), Berkeley.

- Hong Kong University of Science: Hong Kongborn, earned degrees from CalTech and Stanford University, and on faculty of CalTech, Yale University, and the University of California, Los Angeles (UCLA).

- Imperial College London: American-born, left presidency of Lehigh University

- Karolinska Institute: Norwegian-born and educated.

- London School of Economics: Egyptian-born, 
American undergraduate, Oxford University doctorate.

- Oxford University: Irish-born with graduate degrees from UCLA and Harvard University.

- University of British Columbia: on faculty at Harvard University, Johns Hopkins University, Emory University, University College London (UCL), and president, University of Cincinnati.

- University of Edinburgh: German-born and worked at the University of Texas and Xerox PARC

- University of Hong Kong: British-born and scheduled to become vice-chancellor of the University of Aberdeen in 2018.

- University of Illinois: Wales-born, educated at UCL and on faculty at the University of Colorado, Boulder and the University of Michigan.

- University of Melbourne: postgraduate work at UC Berkeley and Harvard University.

\section{A second example of the globalization of university leadership can be observed in the Times Higher Education (THE) World University Rankings for 2017.}

Of the 25 non-American universities' presidents, nearly half (I2) have spent extended periods of time being educated in, or employed by, institutions in a country other than their native one. In comparison, of the top 25 American universities in the THE Rankings, eight presidents or chancellors are foreign-born (Britain, Canada [two], Cuba, India, Iran, Taiwan, and Venezuela) and four Americanborn leaders earned degrees from British universities.

\section{Some Conjectures}

Samples as small as the two presented here are not a base on which to build an explanation for what appears to be an emerging trend in higher education leadership, especially when the countries, cultures, and educational systems examined are as diverse as these. Nevertheless, some conjectures seem warranted.

A good place to start is with the actual selection of presidents and chancellors. Until recently, most countries' methods for selecting university leaders were either an election by professors (and in some cases, other employees of the institution) or selection by governments. That process began changing in recent years and, today, many presidents are selected by formal councils having varying degrees of connection with governments and consisting of a variety of university stakeholders. The other method builds off of a governing board of persons, usually a combination of representatives from within the university, and other, nonacademic persons selected by government. The actual autonomy of such boards varies considerably.

By and large, when the method affords members of the university a preponderant voice, the record is for their choosing an academic, and evidence suggests a preference for a scholar from the country in which the university is located. Familiarity, it seems, does not foster contempt.

Where nonacademics outnumber academics is where it appears there is greater likelihood of a non-native candidate (but still more likely to be an academic) being chosen. This stems from members of the council or board with experience outside academia, especially business and finance, where globalization long ago became a practical reality. A candidate who offers qualifications that include active involvement internationally, including study or academic appointment and success in another country's university, is less of an anomaly to someone whose daily activities include interacting with people around the world and across time zones.

As the role of nonacademics appears to be increasing parallel to national governments granting more autonomy to universities, including their governance by "citizen" boards, we may presume that presidents from other countries are more likely to be strongly considered as candidates. Hence, the nascent trend observed here may well continue and grow.

A second factor promoting the selection of non-native university presidents is that it is part of the even larger growth of international higher education. Estimates of students studying abroad worldwide range from 3.7 to nearly 5 million annually. Year-over-year growth is IO-I2 percent. Data on faculty foreign exchanges from 2OI4-2OI5 and 20I5-20I6 reveal an increase worldwide of more than 7 percent, a continuation of several years during which for all but one year the numbers of professors opting to spend a sustained period of time abroad have increased. More than 300 universities operate campuses abroad where a foreign education provider offers under its own name an entire degree program on-site.

A third conjecture leans on the anecdote of the sort of person who has the courage and initiative to leave one's homeland, family, and friends for another country, culture, and language in order to pursue an education. Such a person is likely to possess the ambition and drive to excel in new surroundings, including that of the university s/he attends; sometimes joins as professor, department chair, dean, provost; and, yes, is selected president.

DOI: http://dx.doi.org/Io.6oI7/ihe.2018.92.IO2II 